\title{
COMPARISON OF RED CELL DISTRIBUTION WIDTH WITH SOFA SCORE AS A PROGNOSTIC MARKER OF SEPSIS IN ELDERLY PATIENTS
}

\author{
Shaikh Mohammed Aslam S1, J. N. Durga Rao Yadavalli² \\ ${ }^{1}$ Associate Professor, Department of Medicine, M. S. Ramaiah Medical College, Bangalore. \\ JJunior Resident, Department of Medicine, M. S. Ramaiah Medical College, Bangalore.
}

\begin{abstract}
\section{BACKGROUND}

Severe sepsis and septic shock are increasing in incidence and contributing significantly to mortality. The prediction of outcome for elderly patients with sepsis may facilitate more aggressive interventions. The SOFA score is a scoring system used to quantify the severity of the patient's illness based on the degree of organ dysfunction.

Various biomarkers are being evaluated for early diagnosis of sepsis. RDW is one of them, which have been shown to predict mortality and morbidity of sepsis. Hence, this study is being done to compare RDW with SOFA score as prognostic marker of sepsis in elderly patients.
\end{abstract}

\section{AIM}

To compare red cell distribution width with SOFA score as a prognostic marker of sepsis in elderly patients.

\section{METHODS}

A total of 93 elderly patients in sepsis who were admitted to Intensive Care Unit of M. S. Ramaiah Hospitals between October 2013 and September 2015 were included in the study. ROC (Receiver Operating Curve) was used to determine the optimal cut-off point for RDW for predicting mortality. ROC of RDW was compared with ROC of SOFA score.

\section{RESULTS}

Mean age of the patients was $70.72 \pm 8.02$ and most of the patients were in the age group of $61-70 y r s .(53.8 \%) .52(55.9 \%)$ patients were males and $41(44.1 \%)$ patients were females. Bronchopneumonia (34.4\%) and urosepsis (30.1\%) were the most common causes of sepsis; $61.3 \%$ of the patients had SOFA score in the range of 5-10. Mean SOFA score was 7.87097 \pm 3.22769 . Mean RDW was $14.247 \pm 2.1151$.

\section{CONCLUSION}

RDW had a sensitivity of $81.6 \%$, specificity of $77.3 \%$, positive predictive value of $80 \%$, and negative predictive value of $79.1 \%$ with a cut-off value of $13.75 \%$ in predicting mortality in elderly patients in sepsis.

\section{KEYWORDS}

Sepsis, Septic Shock, SOFA Score, Red Cell Distribution Width.

HOW TO CITE THIS ARTICLE: Shaikh Mohammed Aslam S, J. N. Durga Rao Yadavalli. "Comparison of Red Cell Distribution Width with Sofa Score as a Prognostic Marker of Sepsis in Elderly Patients." Journal of Evolution of Medical and Dental Sciences 2015; Vol. 4, Issue 99, December 10; Page: 16434-16438, DOI: 10.14260/jemds/2015/2437

\section{INTRODUCTION \\ Worsening sepsis is associated with increased mortality as multiple organ systems fail. Prediction of outcome for patients with sepsis may facilitate more aggressive interventions. The degree of severity is most often quantified by the Sequential Organ Failure Assessment (SOFA) score, which can predict the severity and outcome of multiple organ failure. However, calculating SOFA score is cumbersome. It would be advantageous to identify a biomarker that would be associated with the degree of severity in patients with sepsis. \\ The Red Cell Distribution Width (RDW) is the coefficient of variation of Red Blood Cell (RBC) volume and is a}

Financial or Other, Competing Interest: None.

Submission 23-11-2015, Peer Review 24-11-2015,

Acceptance 04-12-2015, Published 09-12-2015.

Corresponding Author:

Dr. Shaikh Mohammed Aslam S,

Associate Professor, Department of Medicine,

M. S. Ramaiah Medical College,

Bangalore.

E-mail:drmdaslam@yahoo.com

DOI:10.14260/jemds/2015/2437 representation of the RBC size heterogeneity of an individual patient. ${ }^{1}$ RDW is elevated by increased red cell destruction, nutritional deficiencies and blood transfusions. ${ }^{2}$ Biomarkers of chronic inflammation like erythrocyte sedimentation rate and C-reactive protein, have been associated with elevated RDW.3,4 Recent studies have reported that Red Cell Distribution Width (RDW) is associated with prognosis in Critical Illness, Heart Failure, Acute Myocardial Infarction, Pulmonary Embolism, Pneumonia and Cardiac Arrest.5-10

In patients with severe sepsis, early diagnosis and treatment with antibiotics is crucial for survival of patients. Various markers are being tested for early diagnosis of Sepsis. Recent studies have shown that elevated RDW levels are associated with sepsis. RDW as a part of Complete Blood Count (CBC) is tested in all patients in sepsis. Hence, this study was done to see the correlation between RDW and sepsis.

\section{AIMS AND OBJECTIVES OF THE STUDY}

To compare red cell distribution width with SOFA score as a prognostic marker of sepsis in elderly patients. 


\section{METHODOLOGY}

Study was a hospital based prospective observational study conducted over a period of two years from October 2013 to September 2015; 93 elderly patients admitted with sepsis to Intensive Care Units of M.S. Ramaiah Hospitals, Bangalore, were studied.

\section{Inclusion Criteria}

Patients aged $>60$ years admitted to Intensive Care Units (ICU), who met the criteria of sepsis (According to Surviving Sepsis Campaign: International Guidelines for Management of Severe Sepsis and Septic Shock: 2012) were included in the study. ${ }^{11}$

\section{Exclusion Criteria:}

- Blood loss $>10 \%$ blood volume.

- Blood product transfusion in the previous week of admission.

- Recent chemotherapy.

- Previous history of diseases primarily affecting red blood cells.

- Use of drugs known to change morphology and rheology of red blood cells.

\section{METHODS OF DATA COLLECTION}

Ninety three elderly patients in sepsis were included in the study. Purpose of study was explained to the patients and their relatives and informed consent was obtained. Thereafter, the patients were assessed and blood samples for complete blood count including RDW and serum procalcitonin were sent on admission. Other tests such as arterial blood gas, liver function tests, renal function tests, prothrombin time, activated partial thromboplastin time, international normalized ratio, chest $x$-ray, serum electrolytes, blood culture and urine culture were sent in all the patients.

RDW was measured as a part of Automated Complete Blood Count using SYSMEX XE 2100 and XT 2000i.

\section{STATISTICAL ANALYSIS}

Data was entered in MS Excel and analyzed using SPSS version 17. All the continuous variables like age, pulse rate, platelet counts, etc. were described using mean and standard deviation. All the qualitative variables were expressed as percentage. ROC (Receiver Operating Curve) was used to determine the optimal cut-off point for RDW for predicting mortality. ROC of RDW was compared with ROC of SOFA score.

\section{RESULTS}

Most of the patients were in the age group of $61-70 \mathrm{yrs}$. (53.8\%); 52(55.9\%) patients were males and $41(44.1 \%)$ patients were females. (Table 1) Fever (89.2\%) was the most common presenting symptom followed by breathlessness (37.6\%) and cough (32.3\%). (Table 2) Diabetes Mellitus (51.6\%) and Hypertension (46.2\%) were most common comorbid conditions. (Table 3) Bronchopneumonia (34.4\%) and urosepsis (30.1\%) were the predominant causes of sepsis. (Table 4) Mean age of the patients was $70.72 \pm 8.02$ (Table 5), mean total count was 13075.38 \pm 7339.968 (cells $/ \mathrm{mm}^{3}$ ), mean platelet count was 167353.01 \pm 120988.964 (cells $/ \mathrm{mm}^{3}$ ), and mean procalcitonin was $16.526 \pm 23.9572$ (Table 6). Most of the patients (61.3\%) had SOFA score in the range of 5-10. Mean SOFA score was 7.87097 \pm 3.22769 . (Table 7).

RDW had a sensitivity of $81.6 \%$, specificity of $77.3 \%$, positive predictive value of $80 \%$, and negative predictive value of $79.1 \%$ with a cut-off value of $13.75 \%$ in predicting mortality in elderly patients in sepsis. (Graph 1 and Table 8) SOFA score had sensitivity of $95.9 \%$ and specificity of $77.3 \%$ in predicting mortality in elderly patients in sepsis. (Graph 2).

\section{DISCUSSION}

Sepsis is the leading cause of death in non-coronary ICU patients, and the tenth most common cause of death overall according to data from the Centers for Disease Control and Prevention (The first being heart disease). ${ }^{12}$ Sepsis-related incidence and mortality rates increase with age and preexisting comorbidity. Various scoring systems have been developed to predict the outcome in sepsis. Among them one of the widely used scoring systems is SOFA Score.

Sequential Organ Failure Assessment (SOFA) score was constructed using physiological measures of dysfunction in six organ systems (Respiratory, cardiovascular, liver, coagulation, renal and central nervous systems) each of which is graded from 0 to 4 with increasing severity of dysfunction. ${ }^{13}$ The first epsis-related Organ Failure Assessment score, later called the Sequential Organ Failure Assessment (SOFA) score, was introduced in 1994 in a consensus meeting of European society of intensive care medicine and further revised in 1996. The aim was to quantify the severity of the patient's illness based on the degree of organ dysfunction, serially over time.

The Red Blood Cell Distribution Width (RDW), as part of an automated Complete Blood Count (CBC) is a routinely available parameter on hematology analyzers. This parameter is the most commonly reported index of the variation in red cell volume and can be used to detect subtle degrees of anisocytosis. RDW is a numerical measure of anisocytosis. It may be useful in distinguishing certain causes of anemia, in particular in distinguishing Iron Deficiency (RDW raised) from thalassemia (RDW usually normal).

The role of leucocytes in the inflammatory response is well known; nevertheless the rheological changes of Red Blood Cells (RBC) and their physiopathological role during inflammation are not completely understood. Studies by electronic microscopy have founded important alterations in RBC shape during the refractory phase of shock. ${ }^{14,15}$ They also showed morphologic and functional changes during sepsis regarding RBC population. This has brought to discussion the hypothesis that RBC alterations during shock and sepsis may contribute to Multiple Organ Dysfunction Syndrome (MODS). It has been reported previously that the flexibility of RBC may be dysfunctional due to the endotoxins of bacteria in septic shock. The RBC exposed to endotoxin decreased their deformability and showed increased hydroxymyristic acid content which is a component of bacterial endotoxins, suggesting a relationship. ${ }^{16-17}$ As sepsis is an inflammatory state, there will be release of various inflammatory mediators like Interleukin-6, Tumor Necrosis Factor. These proinflammatory cytokines suppress the maturation of red blood cells and decrease the half-life of red blood cells, which in turn results in elevated RDW. 
Recently, highly significant associations have been described between RDW value and all cause, non-cardiac and cardiac mortality in patients with coronary artery disease, acute and chronic heart failure, peripheral artery disease, stroke, pulmonary embolism, and pulmonary artery hypertension.18-23 High RDW has been associated with increased mortality in patients with stroke, liver disease, peripheral arterial disease and organophosphorous compound poisoning. ${ }^{24-28}$ Moreover, several studies have reported that RDW shows the predictive value of all-cause mortality in critically ill or ICU patients, patients with community acquired pneumonia, gram-negative bacteremia and severe sepsis. ${ }^{29-32}$

Sepsis and septic shock are one of the leading causes of death worldwide. Early detection and prompt administration of antibiotics has been shown to reduce mortality and morbidity in patients with sepsis. Hence, various markers have been evaluated for earlier diagnosis of sepsis.

Serum procalcitonin as a diagnostic marker of sepsis has been largely studied in adult population and is an established marker of sepsis, but it is expensive. There are many other markers of sepsis which are being evaluated for its diagnosis among which RDW is emerging as a promising marker. It is a part of Complete Blood Count which is a cheap, easily available test. Hence, we have conducted this study to assess the role of RDW as a prognostic marker of sepsis and septic shock.

In our study, the mean age of the patients was $70.72 \pm 8.02$ and most of the patients were in the age group of 61-70yrs. (53.8\%), which is in accordance with the study done by You Hwan Jo, et al. where the median age group was 75 years in nonsurvivors and 70.5 years in survivors. In our study, $55.9 \%$ of the patients were males. This is in concordance with the studies done by You Hwan Jo, et al. and Zhongheng Zhang et al. where $57.5 \%$ and $65.4 \%$ of the patients respectively were males. ${ }^{32,33}$ In our study, Diabetes Mellitus (51.6\%) and Hypertension (46.2\%) were most common comorbid conditions. This is in concordance with study done by You Hwan Jo, et al. and Sabina Hunziker, et al. where diabetes mellitus and hypertension were the most common comorbid conditions. ${ }^{32,34}$ In the present study, bronchopneumonia (34.4\%) was the most common causes of sepsis. This is in concordance with studies done by You Hwan Jo, et al. (50.2\%) and Leonardo Lorente, et al. (56.6\%), where pneumonia was the most common cause of sepsis. ${ }^{32}$

A $61.3 \%$ of the patients had SOFA score in the range of 5-10. Mean SOFA score was 7.87097 \pm 3.22769 . This was similar to the results observed in studies done by Leonardo Lorente, et al. where median SOFA Score was 6 in survivors and 8 in nonsurvivors.

\section{CONCLUSION}

Established prognostic markers of sepsis like SOFA score requires various parameters to be measured and calculated, which can be cumbersome. RDW as a part of Complete Blood Count is tested in all patients in sepsis. Hence, in elderly patients in sepsis, RDW can be used as a biomarker which is associated with the degree of severity of sepsis.

\begin{tabular}{|c|c|c|c|c|c|}
\hline \multirow{2}{*}{$\begin{array}{c}\text { Age in } \\
\text { Years }\end{array}$} & \multicolumn{2}{|c|}{ Males } & \multicolumn{2}{|c|}{ Females } & Total \\
\cline { 2 - 6 } & $\begin{array}{c}\text { \% Within } \\
\text { Age } \\
\text { Category }\end{array}$ & No. & $\begin{array}{c}\text { \% Within } \\
\text { Age } \\
\text { Category }\end{array}$ & No. \\
\hline $61-70$ & 25 & 50 & 25 & 50 & 50 \\
\hline $71-80$ & 19 & 63.3 & 11 & 36.7 & 30 \\
\hline $81-90$ & 8 & 61.5 & 5 & 38.5 & 13 \\
\hline Total & 52 & 55.9 & 41 & 44.1 & 93 \\
\hline
\end{tabular}

Table 1: Age and Sex Distribution of Patients Studied

\begin{tabular}{|c|c|c|}
\hline \multirow{2}{*}{ Clinical Symptoms } & \multicolumn{2}{|c|}{ Total Patients (93) } \\
\cline { 2 - 3 } & No. & \% \\
\hline Fever & 83 & 89.2 \\
\hline Breathlessness & 35 & 37.6 \\
\hline Cough & 30 & 32.3 \\
\hline Gastrointestinal symptoms & 24 & 25.8 \\
\hline Burning micturition & 23 & 24.7 \\
\hline Others & 37 & 39.8 \\
\hline \multicolumn{2}{|c|}{ Table 2: Clinical Symptoms } \\
\hline
\end{tabular}

\begin{tabular}{|c|c|c|}
\hline Comorbid Conditions & $\begin{array}{c}\text { Number } \\
\text { (n=93) }\end{array}$ & $\mathbf{\%}$ \\
\hline Diabetes mellitus & 48 & 51.6 \\
\hline Hypertension & 43 & 46.2 \\
\hline Ischemic Heart Disease & 29 & 31.2 \\
\hline Chronic Kidney Disease & 15 & 16.1 \\
\hline $\begin{array}{c}\text { Chronic Obstructive } \\
\text { Pulmonary Disease }\end{array}$ & 10 & 10.8 \\
\hline Chronic Liver Disease & 4 & 4.3 \\
\hline \multicolumn{2}{|c|}{ Table 3: Comorbid Conditions } \\
\hline \multicolumn{2}{|c}{} \\
\hline
\end{tabular}

\begin{tabular}{|c|c|c|}
\hline Cause of Sepsis & Number $(n=93)$ & $\%$ \\
\hline Bronchopneumonia & 32 & 34.4 \\
\hline Urosepsis & 28 & 30.1 \\
\hline Soft tissue & 11 & 11.8 \\
\hline Gastrointestinal sepsis & 8 & 8.6 \\
\hline Hepatobiliary & 6 & 6.5 \\
\hline Miscellaneous & 8 & 8.6 \\
\hline \multicolumn{3}{|c|}{ Table 4: Cause of Sepsis } \\
\hline
\end{tabular}

\begin{tabular}{|c|c|}
\hline Variables & Mean \pm SD \\
& \\
\hline Age in years & $70.72 \pm 8.02$ \\
\hline Temperature (o fahrenheit) & $100.353 \pm 1.245$ \\
\hline Heart rate (per minute) & $102.39 \pm 10.817$ \\
\hline SBP(mm Hg) & $102.39 \pm 15.529$ \\
\hline DBP(mm Hg) & $63.29 \pm 13.213$ \\
\hline Respiratory rate (per minute) & $24.01 \pm 5.097$ \\
\hline SpO2(\%) & $93.33 \pm 3.454$ \\
\hline \multicolumn{2}{|c|}{ Table 5: Comparison of Baseline Variables } \\
\hline
\end{tabular}




\begin{tabular}{|c|c|}
\hline Laboratory Parameters & Mean \pm SD \\
\hline Hemoglobin \% (gm/dl) & $\begin{array}{c}11.558710 \pm 2.623 \\
3298\end{array}$ \\
\hline Total count (cells/mm ${ }^{3}$ ) & $\begin{array}{c}13075.38 \pm 7339.9 \\
68\end{array}$ \\
\hline $\begin{array}{c}\text { Platelet count } \\
\text { (cells } / \mathrm{mm}^{3} \text { ) }\end{array}$ & $\begin{array}{c}167353.01 \pm 12098 \\
8.964\end{array}$ \\
\hline ESR (mm/hour) & $43.194 \pm 33.0304$ \\
\hline $\begin{array}{c}\text { Serum Creatinine } \\
\text { (mg/dl) }\end{array}$ & $3.054 \pm 2.6354$ \\
\hline Total Bilirubin $(\mathrm{mg} / \mathrm{dl})$ & $2.206 \pm 4.1525$ \\
\hline Albumin (mg/dl) & $2.613 \pm 1.5070$ \\
\hline $\begin{array}{c}\text { Aspartate transaminase } \\
\text { (IU/L) }\end{array}$ & $189.33 \pm 789.599$ \\
\hline $\begin{array}{c}\text { Alanine transaminase } \\
\text { (IU/L) }\end{array}$ & $131.59 \pm 503.096$ \\
\hline Procalcitonin & $16.526 \pm 23.9572$ \\
\hline RDW & $14.247 \pm 2.1151$ \\
\hline \multicolumn{2}{|c|}{ Table 6: Laboratory Parameters } \\
\hline \multicolumn{2}{|c}{}
\end{tabular}

\begin{tabular}{|c|c|c|}
\hline SOFA Score & Number (n=93) & $\mathbf{\%}$ \\
\hline$<5$ & 17 & 18.3 \\
\hline $5-10$ & 57 & 61.3 \\
\hline $11-15$ & 18 & 19.4 \\
\hline$>15$ & 1 & 1 \\
\hline Total & 93 & 100 \\
\hline \multicolumn{3}{|c|}{ Table 7: SOFA Score } \\
\hline
\end{tabular}

\begin{tabular}{|c|c|c|c|}
\hline RDW & Death & Survived & Total \\
\hline$>13.75$ & 40 & 10 & 50 \\
\hline$\leq 13.75$ & 9 & 34 & 43 \\
\hline Total & 49 & 44 & 93 \\
\hline$\%$ & $52.7 \%$ & $47.3 \%$ & $100.0 \%$ \\
\hline \multicolumn{3}{|c|}{ Table 8: RDW Sensitivity, Specificity, PPV, NPV } \\
\hline
\end{tabular}

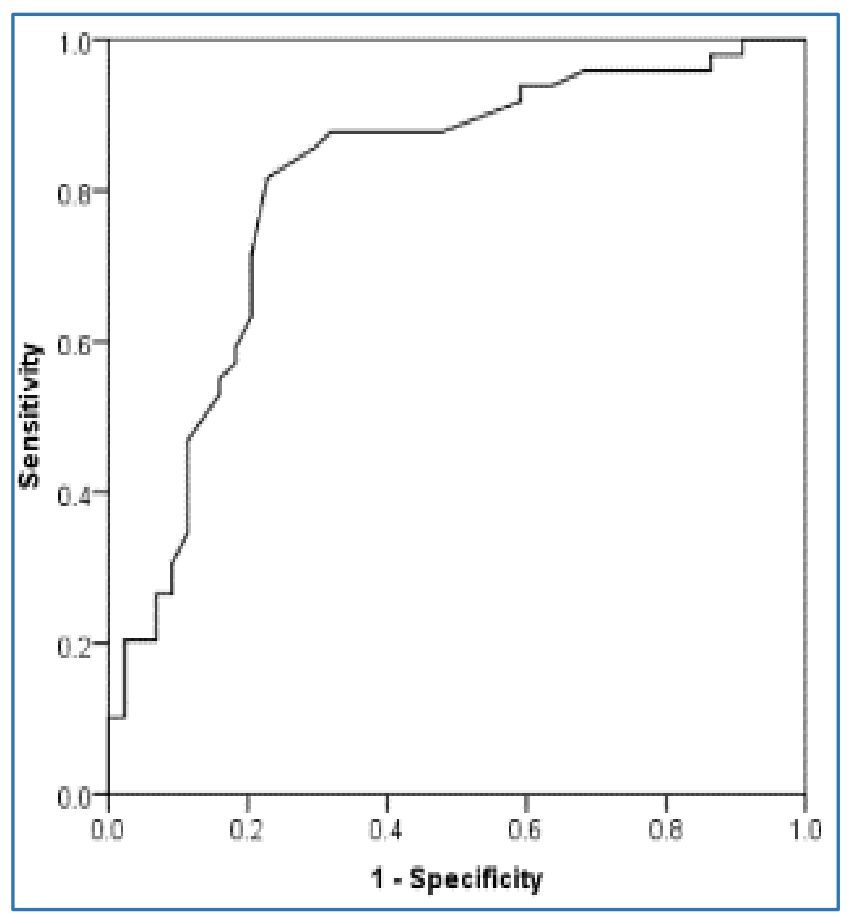

Graph 1: Area under the ROC to determine the cut-off point for RDW

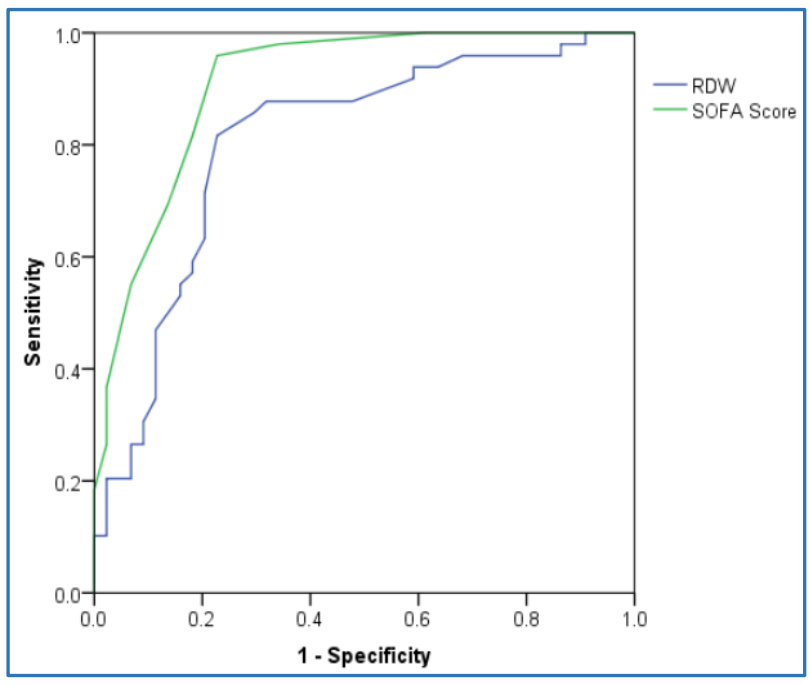

Graph 2: Comparison of area under the ROC between RDW and SOFA Score

\section{REFERENCES}

1. Evans TC, Jehle D. The red blood cell distribution width. J Emerg Med 1991;9 Suppl 1:71-4.

2. Fukuta H, Ohte N, Mukai S, Saeki T, Asada K, Wakami K, et al. Elevated plasma levels of B-type natriuretic peptide, but not C-reactive protein are associated with higher red cell distribution width in patients with coronary artery disease. Int Heart J 2009 May;50(3):301-12.

3. Lippi G, Targher G, Montagnana M, Salvagno GL, Zoppini G, Guidi GC. Relation between red blood cell distribution width and inflammatory biomarkers in a large cohort of unselected outpatients. Arch Pathol Lab Med 2009 Apr;133(4):628-32.

4. Perlstein TS, Weuve J, Pfeffer MA, Beckman JA. Red blood cell distribution width and mortality risk in a communitybased prospective cohort. Arch Intern Med 2009 Mar 23;169(6):588-94.

5. Felker GM, Allen LA, Pocock SJ, Shaw LK, McMurray JJ, Pfeffer MA, et al. Red cell distribution width as a novel prognostic marker in heart failure: data from the CHARM Program and the Duke Databank. J Am Coll Cardiol 2007 Jul 3;50(1):40-7.

6. Dabbah S, Hammerman H, Markiewicz W, Aronson D. Relation between red cell distribution width and clinical outcomes after acute myocardial infarction. Am J Cardiol 2010 Feb 1;105(3):312-7.

7. Zorlu A, Bektasoglu G, Guven FM, Dogan OT, Gucuk E, Ege $\mathrm{MR}$, et al. Usefulness of admission red cell distribution width as a predictor of early mortality in patients with acute pulmonary embolism. Am J Cardiol 2012 Jan 1;109(1):128-34.

8. Braun E, Domany E, Kenig Y, Mazor Y, Makhoul BF, Azzam ZS. Elevated red cell distribution width predicts poor outcome in young patients with community acquired pneumonia.

Crit Care 2011 Aug 11;15(4):R194.

9. Bazick HS, Chang D, Mahadevappa K, Gibbons FK, Christopher KB. Red cell distribution width and all-cause mortality in critically ill patients. Crit Care Med 2011 Aug;39(8):1913-21. 
10. Kim J, Kim K, Lee JH, Jo YH, Rhee JE, Kim TY, et al. Red blood cell distribution width as an independent predictor of all-cause mortality in out of hospital cardiac arrest.

Resuscitation 2012 0ct;83(10):1248-52.

11. Dellinger RP, Levy MM, Carlet JM, Bion J, Parker MM, Jaeschke R, et al. Surviving Sepsis Campaign: international guidelines for management of severe sepsis and septic shock: 2008. Intensive Care Med 2008;34(1):17-60.

12. Hotchkiss RS, Karl IE. The Pathophysiology and treatment of sepsis. N Engl J Med 2003 Jan 9;348(2):138-50.

13. Vincent L, Moreno R, Takala J, Willatts S, De Mendonca A, Bruining $\mathrm{H}$, et al. The SOFA score to describe organ dysfunction/failure. Intensive Care Medicine 1996 Jul;22(7):707-10.

14. Poraicu D, Sandor S, Menessy Y. Decrease of red blood cell filterability seen in intensive care. Red blood cell cremation "in vivo" as morphological evidence of increased red blood viscosity in low flow states. Resuscitation 1983 Aug;10(4):305-16.

15. Aliberti G, Proietta M, Pulignano I, Di Giovanni C, Tritapepe L, Vercillo G, et al. Respiratory changes in human red cells.

Clin Lab Haematol 2001 Dec;23(6):361-3.

16. Betticher DC, Keller H, Maly FE, Reinhart WH. The effect of endotoxin and tumor necrosis factor on erythrocyte and leukocyte deformability in vitro. $\mathrm{Br} \mathrm{J}$ Haematol 1993 Jan;83(1):130-7.

17. Posch JMB, Leray C, Ruef P, Cazenave JP, Linderkamp 0. Endotoxin binding to erythrocyte membrane and erythrocyte deformability in human sepsis and in vitro. Crit Care Med 2003 Mar;31(3):924-8.

18. Sangoi MB, Da Silva SH, da Silva JE, Moresco RN. Relation between red blood cell distribution width and mortality after acute myocardial infarction. Int J Cardiol 2011 Jan 21;146(2):278-80.

19. Lappe JM, Horne BD, Shah SH, May HT, Muhlestein JB, Lappe DL, et al. Red cell distribution width, C-reactive protein, the complete blood count, and mortality in patients with coronary disease and a normal comparison population. Clin Chim Acta 2011 Nov 20;412(23-24):2094-9.

20. Forhecz Z, Gombos T, Borgulya G, Pozsonyi Z, Prohaszka Z, Janoskuti L. Red cell distribution width in heart failure: prediction of clinical events and relationship with markers of ineffective erythropoiesis, inflammation, renal function, and nutritional state. Am Heart J 2009;158:659-666.

21. Allen LA, Felker GM, Mehra MR, Chiong JR, Dunlap SH, Ghali JK, et al. Validation and potential mechanisms of red cell distribution width as a prognostic marker in heart failure. J Card Fail 2010 Mar;16(3):230-8.
22. Pascual-Figal DA, Bonaque JC, Redondo B, Caro C, Manzano-Fernandez S, Sanchez-Mas J, et al. Red blood cell distribution width predicts long-term outcome regardless of anaemia status in acute heart failure patients. Eur J Heart Fail 2009 Sep;11(9):840-6.

23. Hampole CV, Mehrotra AK, Thenappan T, GombergMaitland M, Shah SJ. Usefulness of red cell distribution width as a prognostic marker in pulmonary hypertension.

Am J Cardiol 2009 Sep 15;104(6):868-72.

24. Ani C, Ovbiagele B. Elevated red blood cell distribution width predicts mortality in persons with known stroke. J Neurol Sci 2009 Feb 15;277(1-2):103-8.

25. Hu Z, Sun Y, Wang Q, Han Z, Huang Y, Liu X, et al. Red blood cell distribution width is a potential prognostic index for liver disease. Clin Chem Lab Med 2013 Jul;51(7):1403-8.

26. Lou Y, Wang M, Mao W. Clinical usefulness of measuring red blood cell distribution width in patients with hepatitis B. PLoS One 2012;7(5):e37644.

27. Ye Z, Smith C, Kullo IJ. Usefulness of red cell distribution width to predict mortality in patients with peripheral artery disease.

Am J Cardiol 2011 Apr 15;107(8):1241-5.

28. Shaikh MAS, Akhila AV. Red Cell Distribution Width as Prognostic Marker in Organophosphorous Compound Poisoning IOSR-JDMS Sep. 2015;14(9):21-4.

29. Wang F, Pan W, Pan S, Ge J, Wang S, Chen Ml. Red cell distribution width as a novel predictor of mortality in ICU patients. Ann Med 2011 Feb;43(1):40-6.

30. Lee JH, Chung HJ, Kim K, Jo YH, Rhee JE, Kim YJ, et al. Red cell distribution width as a prognostic marker in patients with community-acquired pneumonia. Am J Emerg Med 2013 Jan;31(1):72-9.

31. Ku NS, Kim HW, Oh HJ, Kim YC, Kim MH, Song JE, et al. Red blood cell distribution width is an independent predictor of mortality in patients with gram-negative bacteremia. Shock 2012 Aug; 38(2):123-7.

32. Jo YH, Kim K, Lee JH, Kang C, Kim T, Park HM, et al. Red cell distribution width is a prognostic factor in severe sepsis and septic shock. Am J Emerg Med 2013 Mar;31(3):545-8.

33. Zhang Z, Xu X, Ni H, Deng H. Red cell distribution width is associated with hospital mortality in unselected critically ill patients.

J Thorac Dis 2013 Dec;5(6):730-736.

34. Hunziker S, Stevens J, Howell MD. Red cell distribution width and mortality in newly hospitalized patients. Am J Med 2012 Mar;125(3):283-91. 